\title{
PENGEMBANGAN MEDIA PEMBELAJARAN TEKA-TEKI SILANG (TTS) PADA PEMBELAJARAN TEMATIK TEMA CITA-CITAKU KELAS IV DI MI AL BUSYRO
}

\author{
${ }^{1)}$ Siti Nurjanah, Fakultas Tarbiyah, Institut Agama Islam Nahdlatul Ulama Tuban, \\ email : sitinurjanah@stitmatuban.ac.id \\ ${ }^{2)}$ Sumarmi, Fakultas Tarbiyah, Institut Agama Islam Nahdlatul Ulama Tuban, \\ email : tikadwi.tuban@gmail.com
}

\begin{abstract}
The use of instructional media really helps teachers develop and deepen the teaching and learning process in the classroom. The use of instructional media that varies appropriately can affect student learning activities, interests and motivation. Therefore, learning media that are not boring are needed. One of them is with game-based media, such as crossword puzzles.

Based on the background and study of the theory, this research is expected to provide answers to the formulation of the problem: (1) What is the validity of the crossword puzzle media on the thematic learning of my ideals for grade IV at MI Al-Busyro? (2) What is the practicality of the crossword media in the thematic learning theme of my ideals grade IV at MI Al Busyro? (3) What is the effectiveness of the crossword puzzle media on the thematic learning of my ideals for grade IV at MI Al Busyro ?.

The objectives in this study are (1) Knowing the validity of the crossword puzzle media on the thematic learning theme of my ideals grade IV at MI Al Busyro? (2) Knowing the practicality of the crossword media in the thematic learning theme of my ideals grade IV at MI Al Busyro? (3) Knowing the effectiveness of the crossword puzzle media in the thematic learning theme of my ideals grade IV at MI Al Busyro?.

This research is a type of research or development known as Research and Development $(R \& D)$. This research was conducted in MI Al-Busyro class IV. The instrument used in the form of a validation sheet to measure validity, questionnaire responses of teachers and students to measure the level of practicality, and items to measure the level of effectiveness through student tests. The data that has been obtained is then analyzed using qualitative and quantitative descriptive data analysis.

Based on the results of the validity analysis, (1) The crossword puzzle media developed are in the very valid category with a value of $90.5 \%$. (2) The results of the teacher's response questionnaire were $93 \%$ and the results of the student's questionnaire responses were $90 \%$ and each was in the very good category. (3) The percentage of student graduation is more than $85 \%$. Thus, it can be concluded that the developed crossword puzzle media meet valid, practical and effective categories.
\end{abstract}

Keywords: Development Of Learning Media, Cross-Text (TTS), Thematic Learning

\section{Pendahuluan}

Kurikulum 2013 sering menjadikan siswa kebingungan dengan materi yang diterimanya, karena semua mata pelajaran digabung menjadi satu dengan tema-tema tertentu. Dengan adanya hal tersebut maka tugas guru adalah memfasilitasi peserta didik untuk lebih 
mengeksplor lingkungan sekitarnya dan tidak hanya terbatas dengan buku tematik saja. Selain itu guru juga harus memberikan materi yang lebih luas dengan cara mencari referensi untuk memperluas pemahaman anak terhadap materi. Hal inilah yang menyebabkan siswa kurang bersemangat dalam belajar.

Sekarang ini, telah banyak media berbasis permainan yang dapat diterapkan oleh guru dalam pembelajarannya. Salah satunya bisa menggunakan media teka-teki silang dalam proses belajar mengajar. Teka-Teki Silang (TTS) adalah suatu media yang sangat tepat untuk mengajarkan materi-materi pembelajaran yang konsepnya untuk mengajarkan ketrampilan siswa dalam menulis, menghafal kosakata, dan media yang menyenangkan karena sifatnya permainan.

Dengan menggunakan permainan Teka-teki silang ini, maka siswa akan merasa lebih tertantang dalam mengerjakan soal yang telah diberikan oleh guru, selain itu siswa akan lebih memahami tentang materi yang telah diberikan, karena hal ini dapat mengatasi kejenuhan siswa yang selama ini hanya menjawab soal-soal yang diberikan dengan model soal pilihan ganda atau uraian.

Berdasarkan latar belakang di atas, maka penulis tertarik untuk melakukan penelitian lebih lanjut dengan judul " Pengembangan Media Teka-Teki Silang (TTS) pada Pembelajaran Tematik Tema Cita-citaku Kelas IV di MI Al Busyro".

Adapun yang menjadi rumusan masalah dalam penelitian ini adalah 1) bagaimana validitas; 2) bagaimana kepraktisan; dan 3) bagaimana keefektifan media teka-teki silang pada pembelajaran tematik tema cita-citaku kelas IV di MI Al Busyro. Selanjutnya, ditinjau dari permasalahan yang telah dirumuskan, maka penelitian ini bertujuan : 1) mengetahui tingkat validitas; 2) mengetahui tingkat kepraktisan; serta 3) mengetahui tingkat keefektifan media tekateki silang pada pembelajaran tematik tema cita-citaku kelas IV di MI Al Busyro.

\section{Kajian Teori}

\section{Media Pembelajaran}

Gerlach \& Ely mengatakan bahwa media apabila dipahami secara garis besar adalah manusia, materi, atau kejadian yang membuat siswa mampu memperoleh pengetahuan, keterampilan, atau sikap. Secara lebih khusus, pengertian media dalam proses belajar mengajar 
cenderung diartikan alat-alat grafis, fotografis, atau elektronis untuk menangkap, memproses, dan menyusun kembali informasi visual dan verbal. ${ }^{1}$

Heinich mengemukakan istilah medium atau media sebagai perantara yang mengantar informasi antara sumber dan penerima. Jadi televisi, film, foto, radio, rekaman audio, gambar yang diproyeksikan, bahan-bahan cetakan, dan sejenisnya adalah media komunikasi. Apabila media tersebut membawa pesan-pesan atau informasi yang mengandung pengajaran maka media tersebut disebut media pembelajaran. ${ }^{2}$

Sedangkan Yudhi Munadi mengatakan bahwa media pembelajaran dapat dipahami sebagai segala sesuatu yang dapat menyampaikan dan menyalurkan pesan dari sumber secara terencana sehingga tercipta lingkungan belajar yang kondusif dimana penerimanaannya dapat melakukan proses belajar secara efisien dan efektif. ${ }^{3}$

Dengan demikian, tujuan pemanfaatan media dalam proses pembelajaran adalah untuk mengefektifkan dan mengefisienkan proses pembelajaran itu sendiri.

\section{Media Teka-Teki Silang}

Teka-teki silang adalah permainan puzzle kata dan pencarian kata yang biasanya berbentuk kotak atau kotak persegi panjang berwarna putih dan hitam. Tujuan permainan ini adalah mengisi kotak putih dengan huruf, membentuk kata atau frasa, dengan memecahkan petunjuk, yang mengarah pada jawaban. Dalam bahasa yang ditulis dari kiri ke kanan, kata dan frasa jawaban ditempatkan di kotak dari kiri ke kanan dan dari atas ke bawah. Kotak yang diarsir digunakan untuk memisahkan kata atau frasa. ${ }^{4}$

Adapun yang dimaksud media pembelajaran teka-teki silang dalam penelitian ini adalah media cetak yang terdapat suatu permainan kata yang berbentuk serangkaian ruang-ruang kosong berbentuk kotak. Tujuan dari permainan ini adalah untuk mengisi kotak dengan huruf, membentuk kata atau frasa tertentu, dengan menyelesaikan petunjuk yang mengarah ke jawaban tertentu.

\section{Langkah-langkah Pembelajaran dengan TTS}

\footnotetext{
${ }_{1}^{1}$ Azhar Arsyad, Media Pembelajaran, Cet ke-16 (Jakarta: Rajawali Pers, 2013), hal. 3

${ }^{2}$ Ibid,. 4

${ }^{3}$ Yudhi Munadi, Media Pembelajaran (Jakarta: Referensi GP press Group, 2013), hal. 7-8

${ }^{4}$ Hilo48, Teka teki silang, https://en.wikipedia.org/wiki/Crossword, diakses tanggal 19 Februari 2020
} 
Model berikut adalah salah satu contoh model pembelajaran yang dapat diaplikasikan dengan media teka-teki silang. Berikut adalah langkah-langkahnya: ${ }^{5}$

(1) Minta siswa untuk membaca materi untuk pertemuan berikutnya dengan seksama.

(2) Siapkan TTS dari materi yang akan diajarkan. Fotokopi kerangka TTS dengan ukuran besar.

(3) Potong daftar pertanyaan kemudian gulung kecil-kecil.

(4) Pada pertemuan yang telah ditentukan, bawa siswa keluar kelas. Bagi menjadi kelompok kecil yang masing-masing terdiri dari 4 siswa. Minta siswa untuk berbaris dengan rapi. Berikan jarak yang sama antara TTS dengan setiap kelompok, 5-10 meter misalnya. Jelaskan aturan permainannya.

(5) Tempelkan kerangka TTS di papan atau tembok.

(6) Guru mengambil soal yang sudah diacak kemudian membacakannya sambil menyetel penghitung waktu (timer) dan mencatat perolehan skor. Siswa yang berbaris terdepan dari tiap kelompok yang mengetahui jawabannya, mengangkat tangan. Setelah dipersilakan oleh guru, siswa yang ada di barisan terdepan boleh menjawab dan menuliskannya pada TTS. Setiap soal dibatasi waktu 1 menit untuk menyelesaikannya. Setelah menjawab, siswa berbaris di paling belakang timnya.

(7) Ulangi proses (6) hingga selesai.

(8) Evaluasi TTS secara bersamaan kemudian hitung perolehan skor masing-masing tim

(9) Berikan panghargaan (reward) bagi tim yang memenangkan permainan.

\section{Pembelajaran Tematik}

Pembelajaran tematik adalah program pembelajaran yang berangkat dari satu tema atau topik tertentu dan kemudian dielaborasi dari berbagai aspek atau ditinjau dari berbagai perspektif mata pelajaran yang biasa di ajarkan di sekolah. Implementasi yang demikian mengacu pada pertimbangan bahan pembelajaran tematik lebih sesuai dengan pekembangan fisik dan psikis anak. $^{6}$

\footnotetext{
${ }^{5}$ Aribowo, E. K. (2017, October 5). Media Pembelajaran DIY: Membuat Flash Card dan Teka-Teki Silang Mandiri. https://doi.org/10.31227/osf.io/nbkg5, diakses 23 Februari 2020.

${ }^{6}$ Kadir dan Hanun, Asrohah. Pembelajaran Tematik (Jakarta: Rajawali Pers, 2014), hal. 1
} 
Pembelajaran tematik adalah pembelajaran tepadu yang menggunakan tema untuk mengaitkan beberapa mata pelajaran sehingga dapat memberikan pengalaman bermakna kepada siswa. Tema adalah pokok pikiran atau gagasan pokok yang menjadi pokok pembicaraan.

Dengan tema diharapkan akan memberikan banyak keuntungan, di antaranya:

1. Siswa mudah memusatkan perhatian pada suatu tema tertentu.

2. Siswa mampu mempelajari pengetahuan dan mengembangkan berbagai kompetensi dasar antar matapelajaran dalam tema yang sama.

3. Pemahaman terhadap materi pelajaran lebih mendalam dan berkesan.

4. Kompetensi dasar dapat dikembangkan lebih baik dengan mengkaitkan matapelajaran lain dengan pengalaman pribadi siswa.

5. Siswa mampu lebih merasakan manfaat dan makna belajar karena materi disajikan dalam konteks tema yang jelas.

6. Siswa lebih bergairah belajar karena dapat berkomunikasi dalam situasi nyata, untuk mengembangkan suatu kemampuan dalam satu mata pelajaran sekaligus mempelajari mata pelajaran lain.

Dapat disimpulkan bahwa pembelajaran tematik adalah pembelajaran terpadu yang memakai tema untuk mengaitkan beberapa mata pelajaran sehingga peserta didik mendapatkan pengalaman yang bermakna. Tema yang dimaksud adalah gagasan pokok atau pokok pikiran yang dijadikan pokok pembicaraan.

\section{Metodologi}

Penelitian ini merupakan jenis penelitian pengembangan atau dikenal dengan istilah Research and Development (R\&D). Lokasi penelitian di MI Al- Busyro kelas IV. Instrrumen yang digunakan berupa lembar validasi untuk mengukur kevalidan, angket respon guru dan siswa untuk mengukur tingkat kepraktisan, serta butir-butir soal untuk mengukur tingkat keefektifan melalui tes siswa. Data yang telah diperoleh kemudian dianalisis dengan menggunakan analisis data deskriptif kualitatif dan kuantitatif.

Pengembangan media pembelajaran pada penelitian ini mengadaptasi pengembangan model 4D (four D model) yang dikembangkan oleh Sivasailam Thiagarajan, Dorothy S. Semmel, 
dan Melvyn I. Semmel. ${ }^{7}$ Pengembangan media pembelajaran model 4D terdiri dari tahap pendefinisian (define), perancangan (design), pengembangan (develop) dan penyebaran (disseminate). Adapun penelitian ini hanya dilakukan hingga pada tahap pengembangan (develop).

\section{Pembahasan}

\section{Analisis Hasil Validasi Media Teka-Teki Silang (TTS)}

Data uji kevalidan media diperoleh melalui lembar validasi. Lembar validasi media pembelajaran digunakan untuk memperoleh informasi tentang kualitas media pembelajaran berdasarkan penilaian para validator ahli. Adapun hasil validasi media, sebagai berikut:

\section{Hasil Validasi Materi}

\begin{tabular}{|c|c|c|c|}
\hline No & Indikator & Pernyataan & Penilaian \\
\hline \multicolumn{4}{|c|}{ Aspek Relevansi Materi } \\
\hline \multirow[t]{3}{*}{ A } & \multirow[t]{3}{*}{$\begin{array}{l}\text { Kelengkapan } \\
\text { materi/isi }\end{array}$} & $\begin{array}{l}\text { 1. Soal yang disajikan sesuai dengan } \\
\text { Kompetensi Inti dan Kompetensi } \\
\text { Dasar }\end{array}$ & 4 \\
\hline & & $\begin{array}{l}\text { 2. Soal yang disajikan mencakup } \\
\text { tujuan pembelajaran }\end{array}$ & 4 \\
\hline & & $\begin{array}{l}\text { 3. Soal yang disajikan sesuai } \\
\text { dengan indikator }\end{array}$ & 4 \\
\hline B & $\begin{array}{l}\text { Keluasan dan } \\
\text { kedalaman materi }\end{array}$ & $\begin{array}{l}\text { 4. Keluasan dan kedalaman soal } \\
\text { dalam batas wajar untuk siswa }\end{array}$ & 3 \\
\hline \multirow[t]{3}{*}{$\mathrm{C}$} & \multirow[t]{3}{*}{$\begin{array}{l}\text { Keakuratan dan } \\
\text { sitematis }\end{array}$} & 5. Soal disajikan secara sistematis & 3 \\
\hline & & 6. Soal yang disajikan jelas & 4 \\
\hline & & $\begin{array}{l}\text { 7. Soal yang disajikan mudah } \\
\text { dipahami }\end{array}$ & 4 \\
\hline \multicolumn{4}{|c|}{ Aspek Penyajian dan Kebahasaan } \\
\hline \multirow[t]{2}{*}{$\mathrm{D}$} & \multirow[t]{2}{*}{$\begin{array}{l}\text { Variasi dalam } \\
\text { penyajian }\end{array}$} & $\begin{array}{l}\text { 8. Dilengkapi gambar sesuai } \\
\text { dengan materi }\end{array}$ & 4 \\
\hline & & $\begin{array}{l}\text { 9. Dilengkapi kata pengantar, daftar } \\
\text { isi, petunjuk penggunaan media } \\
\text { dan tujuan pembelajaran }\end{array}$ & 4 \\
\hline
\end{tabular}

\footnotetext{
${ }^{7}$ Thiagarajan, S., Semmel, D. S \& Semmel, M. I. Instructional Development for Training Teachers of Expectional Children (Minneapolis, Minnesota: Leadership Training Institute/Special Education, University of Minnesota), hal. 5
} 


\begin{tabular}{|l|l|c|c|}
\hline E & Ketepatan bahasa & $\begin{array}{c}\text { 10. Bahasa yang digunakan baik dan } \\
\text { benar sesuai kaidah tata Bahasa } \\
\text { Indonesia }\end{array}$ & 4 \\
\hline \multicolumn{2}{|l}{ Total } & 38 \\
\hline
\end{tabular}

Hasil Validasi Media

\begin{tabular}{|c|c|c|c|}
\hline No & Indikator & Pernyataan & Penilaian \\
\hline \multicolumn{4}{|c|}{ Aspek Kegrafikan } \\
\hline \multirow{3}{*}{ A } & \multirow{3}{*}{ Desain buku } & $\begin{array}{l}\text { 1. Desain cover dan isi buku } \\
\text { sesuai dengan materi yang } \\
\text { disampaikan }\end{array}$ & 4 \\
\hline & & 2. Variasi gambar & 4 \\
\hline & & 3. Komposisi warna & 3 \\
\hline \multirow{3}{*}{ B } & \multirow{3}{*}{ Tipografi buku } & $\begin{array}{l}\text { 4. Huruf yang digunakan } \\
\text { menarik dan mudah dibaca }\end{array}$ & 4 \\
\hline & & 5. Kejelasan tulisan & 3 \\
\hline & & 6. Ukuran huruf & 3 \\
\hline \multicolumn{4}{|c|}{ Aspek Motivasi } \\
\hline \multirow{3}{*}{$\mathrm{C}$} & \multirow{3}{*}{$\begin{array}{l}\text { Keterlaksanaan } \\
\text { Pembelajaran }\end{array}$} & $\begin{array}{l}\text { 7. Media TTS sebagai sumber } \\
\text { belajar }\end{array}$ & 4 \\
\hline & & $\begin{array}{l}\text { 8. Media mampu meningkatkan } \\
\text { motivasi siswa dalam belajar }\end{array}$ & 3 \\
\hline & & $\begin{array}{l}\text { 9. Siswa lebih aktif dalam } \\
\text { melakukan kegiatan belajar }\end{array}$ & 3 \\
\hline \multicolumn{3}{|c|}{ Total } & 31 \\
\hline
\end{tabular}

a. Hasil penilaian validasi materi

$$
\begin{aligned}
& P=\frac{38}{40} \times 100 \\
& =95 \%
\end{aligned}
$$

b. Hasil penilaian validasi media

$$
\begin{aligned}
& P=\frac{31}{36} \times 100 \\
& =86 \%
\end{aligned}
$$


Berdasarkan hasil yang diperoleh di atas, diperoleh nilai rata-rata dari kedua validator tersebut adalah 90,5\%. Mengacu pada tabel kriteria kevalidan, maka prototype berada pada kategori sangat valid dengan nilai $76 \%-100 \%$.

Setelah kedua validator memberikan hasil penilaiannya pada lembar validasi, terdapat beberapa koreksi serta masukan yang diberikan oleh kedua validator terhadap prototype 1 yang dapat dijadikan sebagai bahan dasar untuk merevisi dan hasilnya dapat dilihat pada tabel, sebagai berikut:

\section{Daftar Revisi Prototype 1}

\begin{tabular}{|c|c|c|c|}
\hline No & Aspek & Sebelum Revisi & Setelah Revisi \\
\hline 1 & Cover & Desain cover terlalu kaku & $\begin{array}{c}\text { Cover didesain } \\
\text { lebih menarik }\end{array}$ \\
\hline 2 & Komponen & $\begin{array}{c}\text { Kalimat pertanyaannya terlalu } \\
\text { panjang }\end{array}$ & $\begin{array}{c}\text { Pemilihan kalimat lebih } \\
\text { sederhana dan mudah } \\
\text { dipahami }\end{array}$ \\
\hline 3 & Motivasi & $\begin{array}{c}\text { Belum ada kata-kata bijak } \\
\text { sebagai motivasi anak }\end{array}$ & $\begin{array}{c}\text { Ditambahkan quotes } \\
\text { penyemangat }\end{array}$ \\
\hline
\end{tabular}

Berdasarkan hal tersebut, maka dilakukan revisi kembali terhadap prototype 1 dan hasil revisi disebut sebagai prototype 2 .

\section{Analisis Hasil Uji Kepraktisan Media Teka-Teki Silang}

Pada uji kepraktisan media, diperoleh melalui lembar angket respon guru dan angket respon siswa. Angket ini digunakan untuk memperoleh data mengenai kepraktisan media pembelajaran yang dikembangkan. Adapun hasil angket respon guru dan angket respon siswa, sebagai berikut:

Hasil Angket Respon Guru

\begin{tabular}{|c|c|c|c|}
\hline No & Indikator & Pernyataan & Penilaian \\
\hline \multicolumn{4}{|c|}{ Aspek Materi dan Media } \\
\hline \multirow[t]{3}{*}{$\mathrm{A}$} & \multirow{3}{*}{$\begin{array}{l}\text { Kelayakan } \\
\text { Materi }\end{array}$} & 1. Media ini sesuai dengan KI dan KD & 5 \\
\hline & & $\begin{array}{l}\text { 2. Media ini mencakup tujuan } \\
\text { pembelajaran }\end{array}$ & 4 \\
\hline & & $\begin{array}{l}\text { 3. Soal yang disajikan sesuai dengan } \\
\text { indikator }\end{array}$ & 5 \\
\hline
\end{tabular}




\begin{tabular}{|c|c|c|c|}
\hline & & $\begin{array}{l}\text { 4. Keluasan dan kedalaman soal dalam } \\
\text { batas wajar untuk siswa }\end{array}$ & 5 \\
\hline & & $\begin{array}{l}\text { 5. Media ini dibuat bervariasi dalam } \\
\text { penyajiannya }\end{array}$ & 5 \\
\hline \multirow[t]{2}{*}{ B } & \multirow{2}{*}{$\begin{array}{l}\text { Kepraktisan } \\
\text { media }\end{array}$} & 6. Media ini mudah digunakan & 4 \\
\hline & & $\begin{array}{l}\text { 7. Media ini dapat digunakan tanpa } \\
\text { ketrampilan khusus }\end{array}$ & 4 \\
\hline \multirow[t]{3}{*}{$\mathrm{C}$} & \multirow[t]{3}{*}{$\begin{array}{l}\text { Keluwesan } \\
\text { media }\end{array}$} & $\begin{array}{l}\text { 8. Media ini sederhana dan mudah dibuat } \\
\text { dengan fasilitas sederhana }\end{array}$ & 5 \\
\hline & & $\begin{array}{l}\text { 9. Ukuran media memadai untuk } \\
\text { digunakan semua siswa dalam ruang } \\
\text { kelas }\end{array}$ & 5 \\
\hline & & $\begin{array}{l}\text { 10. Media ini dapat digunakan secara } \\
\text { berkelompok ataupun secara individu }\end{array}$ & 5 \\
\hline \multicolumn{4}{|c|}{ Aspek Motivasi } \\
\hline \multirow[t]{2}{*}{ D } & \multirow[t]{2}{*}{$\begin{array}{l}\text { Keterlaksanaan } \\
\text { pembelajaran }\end{array}$} & $\begin{array}{l}\text { 11. Media ini dapat membuat siswa lebih } \\
\text { aktif dalam pembelajaran }\end{array}$ & 4 \\
\hline & & $\begin{array}{l}\text { 12. Media dapat menarik minat siswa untuk } \\
\text { belajar }\end{array}$ & 5 \\
\hline \multicolumn{3}{|c|}{ Total Nilai } & 56 \\
\hline
\end{tabular}

\section{Hasil Angket Respon Siswa}

\begin{tabular}{|c|c|c|c|c|c|c|c|}
\hline \multirow{2}{*}{ No } & \multirow{2}{*}{ Pernyataan } & \multicolumn{5}{|c|}{ Penilaian } & \multirow{2}{*}{$\begin{array}{l}\text { Rata- } \\
\text { Rata }\end{array}$} \\
\hline & & 1 & 2 & 3 & 4 & 5 & \\
\hline 1 & $\begin{array}{l}\text { Tampilan gambar dan warna } \\
\text { pada media TTS ini serasi } \\
\text { sehingga saya tertarik untuk } \\
\text { menggunakannya. }\end{array}$ & & & & 4 & 6 & 46 \\
\hline 2 & $\begin{array}{l}\text { Media TTS ini mudah } \\
\text { digunakan sehingga saya senang } \\
\text { menggunakannya. }\end{array}$ & & & & 6 & 4 & 44 \\
\hline 3 & $\begin{array}{l}\text { Huruf yang digunakan dalam } \\
\text { media Teka-teki silang ini } \\
\text { menarik }\end{array}$ & & & & 5 & 5 & 45 \\
\hline 4 & $\begin{array}{l}\text { Soal-soal TTS yang disajikan } \\
\text { sesuai dengan pokok bahasan } \\
\text { yang telah dipelajari. }\end{array}$ & & & & 6 & 4 & 44 \\
\hline 5 & $\begin{array}{l}\text { Soal dalam TTS yang disajikan } \\
\text { sesuai dengan tujuan } \\
\text { pembelajaran. }\end{array}$ & & & & 8 & 2 & 42 \\
\hline
\end{tabular}




\begin{tabular}{|c|l|l|l|l|l|c|}
\hline 6 & $\begin{array}{l}\text { Kalimat yang digunakan dalam } \\
\text { media TTS ini mudah } \\
\text { dimengerti. }\end{array}$ & & 1 & 3 & 6 & 43 \\
\hline 7 & $\begin{array}{l}\text { Soal yang disajikan pada media } \\
\text { TTS ini mendorong } \\
\text { keingintahuan saya }\end{array}$ & & & 6 & 4 & 44 \\
\hline 8 & $\begin{array}{l}\text { Dengan media TTS ini membuat } \\
\text { saya lebih aktif dalam } \\
\text { pembelajaran tematik. }\end{array}$ & & 1 & 6 & 3 & 42 \\
\hline 9 & $\begin{array}{l}\text { Melalui media ini saya merasa } \\
\text { tidak canggung berinteraksi } \\
\text { dengan siswa lainnya. }\end{array}$ & & 1 & 9 & 49 \\
\hline 10 & $\begin{array}{l}\text { Media TTS ini membuat saya } \\
\text { semangat untuk mempelajari } \\
\text { materi terkait. }\end{array}$ & & & 4 & 6 & 46 \\
\hline 11 & $\begin{array}{l}\text { Penggunaan media TTS dalam } \\
\text { pembelajaran tematik tidak } \\
\text { membosankan. }\end{array}$ & & & 1 & 9 & 49 \\
\hline 12 & $\begin{array}{l}\text { Saya tertarik menggunakan } \\
\text { media TTS ini dalam } \\
\text { pembelajaran tematik. }\end{array}$ & & & & \\
\hline \multicolumn{2}{|c|}{ Total Nilai } \\
\hline
\end{tabular}

a. Hasil penilaian angket respon guru

$$
\begin{aligned}
P & =\frac{56}{60} \times 100 \\
& =93 \%
\end{aligned}
$$

b. Hasil penilaian angket respon siswa

$$
\begin{aligned}
& P=\frac{542}{600} \times 100 \\
& =90 \%
\end{aligned}
$$

Berdasarkan data tersebut, didapatkan hasil penilaian respon guru adalah 93\% yang berarti tingkat kepraktisan media berada pada kategori sangat baik berdasarkan tabel kriteria kepraktisan dengan rentang nilai berkisar pada $81 \%-100 \%$. Hal ini, berarti media dapat dikatakan praktis menurut guru tematik. Sedangkan penilaian hasil respon siswa adalah $90 \%$ yang berarti tingkat kepraktisan media berada pada kategori sangat baik berdasarkan tabel kriteria kepraktisan dengan rentang nilai berkisar pada $81 \%-100 \%$. Media teka-teki silang telah memenuhi syarat kepraktisan. 


\section{Analisis Hasil Uji Keefektifan Media Teka-Teki Silang (TTS)}

Pada uji keefektifan media, diperoleh melalui tes hasil belajar siswa yang dilakukan pada akhir pembelajaran. Tes hasil belajar menggunakan tes tulis dalam bentuk pilihan ganda dengan jumlah soal sebanyak 20 butir soal. Adapun hasil tes siswa, sebagai berikut:

\section{Hasil Tes Siswa Kelas IV MI Al-Busyro}

\begin{tabular}{|c|l|c|}
\hline No & Nama Siswa & $\begin{array}{c}\text { Nilai Tes Hasil Belajar } \\
\text { (Cita-Citaku) }\end{array}$ \\
\hline 1 & AP & 90 \\
\hline 2 & ARDC & 85 \\
\hline 3 & MM & 85 \\
\hline 4 & MKN & 80 \\
\hline 5 & NZ & 65 \\
\hline 6 & NRA & 85 \\
\hline 7 & PS & 85 \\
\hline 8 & RMA & 95 \\
\hline 9 & ZAP & 95 \\
\hline 10 & MNN & 80 \\
\hline
\end{tabular}

Prosentase Ketuntasan Belajar Siswa

\begin{tabular}{|c|c|c|c|}
\hline No & Ketuntasan Siswa & $\begin{array}{c}\text { Jumlah siswa } \\
\text { (cita-citaku) }\end{array}$ & KKM \\
\hline 1 & Siswa yang tuntas & 9 & \multirow{2}{*}{73} \\
\hline 2 & Siswa yang tidak tuntas & 1 & \\
\hline \multicolumn{2}{|c|}{ Presentase ketuntasan belajar } & \multicolumn{2}{|c|}{$90 \%$} \\
\hline
\end{tabular}

Berdasarkan data di atas, rata-rata prosentase kentutasan belajar siswa sebesar $90 \%$. Jumlah siswa yang lulus pada tes belajar sebanyak 9 orang dan jumlah siswa yang tidak lulus sebanyak 1 orang. Dengan demikian media dapat dikatakan efektif, karena persentase kelulusan siswa lebih dari $85 \%$. 


\section{Kesimpulan}

Berdasarkan hasil analisis data yang diperoleh, maka dapat disimpulkan bahwa:

1. Tingkat kevalidan media teka-teki silang pada pembelajaran tematik kelas IV di MI ALBusyro yang diperoleh dari validator rata-ratanya adalah 90,5\% dimana berada pada kategori sangat valid pada kisaran nilai $76 \%$ - 100\%.

2. Tingkat kepraktisan media teka-teki silang pada pembelajaran tematik kelas IV di MI ALBusyro yang diperoleh dari angket respon guru sebesar 93\% dan angket respon siswa sebesar 90\% masing- masing berada pada tingkat kepraktisan kategori sangat baik. Media memiliki tingkat kepraktisan yang telah memenuhi syarat kepraktisan.

3. Tingkat keefektifan media teka-teki silang pada pelajaran tematik kelas IV di MI AL-Busyro yang diperoleh melalui hasil tes belajar siswa memiliki rata-rata persentase kelulusan sebesar 90\%, dengan demikian media dapat dikatakan efektif, karena persentase kelulusan siswa lebih dari $85 \%$.

\section{Daftar Referensi}

Arsyad, Azhar, Media Pembelajaran, Cet ke-16, Jakarta: Rajawali Pers, 2013.

Asrohah, Hanun dan Kadir. Pembelajaran Tematik, Jakarta: Rajawali Pers, 2014.

E. K, Aribowo, (2017, October 5). Media Pembelajaran DIY: Membuat Flash Card dan TekaTeki Silang Mandiri. https://doi.org/10.31227/osf.io/nbkg5, diakses 23 Februari 2020.

Hilo48, Teka teki silang, https://en.wikipedia.org/wiki/Crossword, diakses tanggal 19 Februari 2020

Munadi, Yudhi, Media Pembelajaran, Jakarta: Referensi GP press Group, 2013.

Tegeh, I Made, dkk. Model Penelitian Pengembangan. Yogyakarta: Graha Ilmu, 2014.

Thiagarajan, S., Semmel, D. S \& Semmel, M. I. Instructional Development for Training Teachers of Expectional Children, Minneapolis, Minnesota: Leadership Training Institute/Special Education, University of Minnesota. 